\title{
Teacher Certification in Indonesia: An Education Policy Analysis
}

\author{
Nurhattati $^{1{ }^{* *}, \text { Matin }^{1} \text {, Agung Dharmawan Buchdadi }}{ }^{2}$, Choirul Fuad Yusuf ${ }^{3}$ \\ ${ }^{1}$ Faculty of Education, Universitas Negeri Jakarta, Indonesia \\ ${ }^{2}$ Faculty of Economics, Universitas Negeri Jakarta, Indonesia \\ ${ }^{3}$ Research \& Development Agency, Ministry of Religious Affairs, Indonesia
}

Received January 2, 2020; Revised April 16, 2020; Accepted April 27, 2020

Copyright $\bigcirc 2020$ by authors, all rights reserved. Authors agree that this article remains permanently open access under the terms of the Creative Commons Attribution License 4.0 International License

\begin{abstract}
This study examines the teacher certification policy in Indonesia. This program is one of the important government policies in enhancing the quality of education. After more than half a century, the teachers' professionalism is not the main issue in the education system in Indonesia. The study was conducted through the use of a qualitative method by applying the Context, Input, Process, Product (CIPP) model. Data was collected through in-depth interviews, observation, and documentation of the research informants comprising official certification documents. The data collected was analyzed through the process of data condensation, data display, and conclusion drawing/ verifications. The analysis conducted revealed that: 1) the purpose of certification is well-defined, well-understood and well-operated; 2) planning and the allocation of resources were classified accordingly; the process of certification has been initiated with socialization, assignment of participants, certification paths, as well as teacher training and development, and as a whole has followed the guidelines of the central government; (4) the results of certification in terms of teacher performance have shown the ability to plan good learning, manage and evaluate student learning. This study proposes to the government to maintain consistency in teacher performance, class-based performance appraisals, which are needed on post-certification continually. It is expected that this study would be an essential reference for the relevant researchers, educational practitioners, and policymakers to develop better teacher certification systems.
\end{abstract}

Keywords Professional Teacher, Teacher Certification Program, CIPP Model

\section{Introduction}

Education is considered as the most effective instrument for changing of nearly all aspects of life-social, economic, cultural, etc.. The national development is greatly influenced and shaped by the quality of its education. Quality of education ensures welfare, prosperity, security, and peaceful life. In its process, the quality of education is assessed or evaluated through the quality of the curriculum, teacher, student, teaching method, school environment, government financing, and linkage with other related institutions. In a more specific spectrum, the quality of education is determined by the quality of learning that teachers do or interact with students. Teachers play a basic and dynamic role in determining the quality of educational effectiveness. The quality of education will systematically be depended on the quality of the teachers themselves. Studies on the relationship between the role of teacher and learning effectiveness show that effective teachers are the most important factor contributing to student achievement. A study conducted by Miguel \& Barsaga (1997) considered factors affecting students' performance focusing on the variables of teacher, student, parent, and community concluded that the teacher was the key factor in student achievement. Hence, the quality of education unavoidably depends on the quality of teachers, particularly in the initial stage (Kulshrestha \& Pandey, 2013). Several similar studies focus on how far the role of the teacher has affected the quality of the teaching-learning process, particularly in the classroom. Almost all agreed that teacher competency is one of the most important school-based resources in determining a student's future academic success and lifetime outcome (Chetty, Friedman, \& Rockoff, 2013; Rivkin, Hanushek, \& Kain, 2005). More recent studies conducted in several developing countries show that the teacher's contribution to the success of the learning process is $34 \%$, management $22 \%$, facilities $26 \%$, and learning time $18 \%$ (Jalal et al., 2009). As a result, there has been a strong emphasis on improving teacher effectiveness in terms of growth in student learning as a means of enhancing student learning. Therefore, the teacher's 
contribution is the highest and the most. These conditions require professional teachers who have sufficient competencies standard, at least consisting of high commitment, knowledge, and skills both for teaching and organizing the classroom. Without adequate professional competencies, teachers become unable to carry out their duties adequately. It is in line with the argument that Teachers' effectiveness appears strongly related to the preparation they have received for teaching. Hence, the higher quality of teachers, the higher quality of teaching, and the higher the quality of teaching, the higher the quality of education. Above all, whatever its condition, high quality of education needs professionally qualified teachers. What means by the professional teacher is a teacher who has: 1) personal maturity, confidence, trustworthiness, and respect for others; 2) analytical and conceptual thinking skills; 3) planning and expectation abilities, initiatives, and continual improvement; 4) has leadership skills such as flexibility, managing students accountability and love learning; and 5) relationships with others such as working in teams and understanding others (Maister, 1997). In accordance with Indonesia Law Number 14 of 2005 concerning Teachers and Lecturers, describes professional teachers as having: (1) talent, interest, calling, and idealism; (2) commitment to improve the quality of education, faith, piety, and noble character; (3) academic qualifications and educational background according to the field of work; (4) competencies required are in accordance with the field of work; (5) responsibility for carrying out professional tasks; (6) obtain an income determined in accordance with work performance; (7) the opportunity to develop professionalism in a sustainable manner by lifelong learning; (8) guarantee of legal protection in carrying out professional duties; and (9) professional organizations that have the authority to regulate matters related to the professionalism of teachers(Undang Undang Republik Indonesia No 14 Tentang Guru dan Dosen, 2005). The professionalism of teachers in their praxis is at least proven by two things. First, ownership of academic qualifications, minimum educational background level S-1 (undergraduate) or D4 (Diploma 4). Second, recognition of the position of teachers as professionals as evidenced by certification. The recognition serves to raise the dignity and role of teachers as agents of learning in improving the quality of national education (Vieira \& DeVoogd, 2013). One of the best strategic ways to improve the quality of teachers is to meet the professional qualifications required as professionals through a teacher certification program. Through this program, the teacher's teaching competencies will be increased besides gaining monetary rewards (Jalal et al., 2009). Teachers certification refers to the National Commission on Educational Services (NCES) is"...a procedure whereby the state evaluates and reviews a teacher candidate's credentials and provides him or her a license to teach". Goldhaber \& Brewer, (2000) highlighted that teacher certification requirement has contended that teaching is a profession that requires specialized skills and that certification ensures at least minimal standards in teacher quality. Teacher certification is needed, at least for increasing the teachers' quality. However, the study conducted by Goldbaher and Brewer concluded that there is little rigorous evidence that systematically teacher certification is related to student achievement. Though finally, the studies suggested the systematic training remains important for teachers.

\section{Teacher Certification in Indonesia}

On behalf of the improvement on the quality of education in Indonesia, the governments, both local and central Government of Indonesia, have committed to allocation $20 \%$ of their budget to education since 2009 . Most of the central government spending on education has been to the local government at the district level to support compulsory nine-year education (primary and secondary levels). One of the central Government implements a program of quality improvement through teacher certification.

Teacher certification is designed for teachers in service and those already having the under-graduate degree (Strata 1) or Diploma IV certificate. Under the teacher certification program, those who considered fulfilling the standard of competency consisting of personal, pedagogical, social, and professional competences are given certificates and professional salaries, incentives, and the chance for career promotion. While those who are not qualified will get any chance to complete their opportunity to attend the training course and take a competence examination.

To come up with high standards of education, teachers' quality must be high as well. In recognition of the significance of quality teachers, a variety of educational policies have been implemented by the Central Government of Republic of Indonesia, through the Ministry of National Education launched programs of teacher certification in 2006, but the program was postponed and started in 2007 due to a redesign of the testing recruitment. Hence the first wave of 200.000 teachers undertook the certification in this year. Through the program, it is expected that by 2015 certified teachers will be professionally able to teach in the country. Since 2007, the process of teachers certification is handled through two institutions, namely the Ministry of National Education (MONE) and the Ministry of Religious Affairs (MORA). The program is aimed at certifying Indonesia teachers both state and private school teachers in service by 2015, mandated by the Act of the Republic of Indonesia No. 20/2003 on National Education System, Law No.14/2005 on Teacher and Lecturer, and Government Regulation of No.19/2005 on National Educational Standard, which 
requires teachers possessing professional certificates to be able to teach. Teachers, as professionals, need certification as one of the best ways to meet their qualifications. Certification is related to the need for ensuring that teachers as professionals possess the qualities which can contribute to the success in achieving quality education. Teacher certification, in a detail aims at: (1) determining teacher eligibility in carrying out tasks as learning agents and realizing national education goals; (2) improving the process and quality of educational outcomes; (3) improving teacher dignity; (4) increasing teacher professionalism; (5) improving teacher welfare. Granting a professional certificate (certification) is done through a set of tests that measure not only the expertise in their fields, but also the competencies they have, which lead to a combination of knowledge, skills, and attitudes towards the expertise in their field.

Various efforts to accelerate the achievement of the target have been carried out by the government. There are three different patterns implemented since 2012, through which a teacher may follow the certification, depending on their qualification, namely: Pemberian Sertifikat Pendidikan Langsung (PSPL) or direct certification, (2) Penilaian Portofolio (PF) or portfolio assessment, and (3) Pendidikan dan Latihan Profesi Guru (PLPG) - or Teacher Retraining. To those who have a Master or Doctorate degree and have a IVB civil service rank or all teachers who have IVC civil rank are eligible to follow a direct certification, and they are only required to follow document certification process and directly are considered as qualified teachers according to the Teacher Law, and they will be directly granted a teacher certificate. Further, to those who are not considered qualified will have to go through the competency tests contained in the teacher retraining channel. The third channel is special for those teachers who hold a supervisory position to follow the certification through the portfolio assessment through the appraisal and verification of various documents which reflect a teacher's competency, covering components of (a) academic qualifications, (b) education courses and training, (c) teaching experience, (d) teaching planning and implementation, (e) appraisals by superior and supervisor, (f) academic achievements, (vii) professional development works, (g) participation in scientific forums, (h) experience in education and social organizations, and (i) relevant recognition and awards in education. Teachers who do not pass the portfolio assessment will also have to go through the competency tests. In fact, in the initial years of the teacher certification program, most teachers were assessed through the portfolio channel that the result was called debates pro-contra. The teacher certification programs implemented for more than 10 years were viewed as problematic and faced many challenges. Some studies show the fact that the teacher certification policy implemented was not capable of assessing the teacher's competencies and skills. Generally, teacher certification failed to measure the actual professional competencies, primarily the program used the portfolio and self-appraisal as the main instrument. As a consequence, the implementation of teacher certification has invited a debate amongst observers.

Rated as a signal of quality, teacher certification has been investigated at various levels, including full standard certification, emergency certification, advanced or National Board Certification, and subject-area certification. Level of teacher certification effectiveness varied in accordance with the difference of perspective, paradigm, or point of view used to evaluate it. The evidence from the United States of America on the effect of teacher certification on teachers' quality and student learning effectiveness, for example, is unavoidably still in debate amongst experts. A number of studies to examine how far the effect of teacher certification program on teacher's quality, student achievement, and professional quality improvement have extensively been done in many countries. Green, Hedgesm \& Laine\& et.al (1996) argue that there is a considerable positive correlation between student achievement and school input, including teacher certification. A supporting study done by Rice (2003) who investigated the effects of teachers' program certification drew a conclusion that there is a positive effect of certified teachers on high school mathematics achievement. But she was still doubtful and highlighted clear that only a little clear impact of emergency or alternative-route certification in either mathematics or science, as compared to teachers who acquire standard certification. On the contrary, studies conducted by Darling-Hammond and her colleagues at Stanford University published data from the Houston Independent School District showed that the Teach for America instructors were less effective than the graduates of the regular teacher certification program (Darling-hammond, 2002). They also concluded that the Teach for America teachers are about effective as other uncertified teachers (Darling-hammond, Holtzman, Gatlin, $\&$ Heilig, 2005). Another study on the same focus on the correlation of the teacher certification program with the teacher competencies and student achievement showed different findings. As a matter of fact, the full program of certification is either unrelated or positively related to student achievement (Darling-hammond, 2000, 2002). The teacher for American instructors were less effective than the graduates. Goe and Stickler (2008)concluded that Teachers' certification status had very little impact on student achievement in American schools in general. There may be differences in knowledge and skills between the certified and uncertified, but these differences are not pronounced to be picked up in student achievement gains. Kane, Rockoff and Staiger (2008) even further reported no difference in the average impact on student achievement between traditionally certified teachers and those who entered teaching without certification.

The same debate on the effect of the certification 
program also happened in Indonesia amongst observers. Some recent studies(Brotosedjati, 2012; Dewanto, Erviantono, \& Winaya, 2016; GUSTINA, 2016; Ulfah, 2012) focusing on the effect of teacher's certification to teacher's performance, noted that teacher's certification programs implemented by both central and local government have positive effects on quality of students learning in all level of education - both at the basic and high education level. In addition, Sutopo (2017), who studied teacher certification for senior vocational school teachers, even concluded that the certification program has a positive contribution to the teacher's quality. In short, teacher certification programs were significantly effective on behalf of improving the quality of teachers. A teacher certification was regarded as the best way to increase teacher's performance including teaching skills, teaching motivation, and economic welfare, at least for amongst researchers who saw the program in the first wave of implementation in the year of 2007-2013

However, other studies conducted by Nurhattati (2017) who evaluated the teacher certification effectiveness and carried out through self-appraisal and portfolio of teacher's experiences in Indonesia clearly showed that there was only a slight difference between those who have been certified and have not been certified in case of their professional competence as teachers. The study compared students' test scores on math, science, Indonesian, and English between those who taught by certified teachers, and those by uncertified ones demonstrated neither a significant difference between the groups nor the influence of certified on student achievement (Abbas, 2013). What was significantly seen is, in fact, the programs increased teachers' welfare because they got benefits from allowance which made them confident and proud of their profession. In line with such finding, on 10 July 2018 on the forum of Public Dialogue on National Education, PGRI Sri Mulyani Indrawati Minister of Finance of Republic of Indonesia reminds again about the effectiveness of teacher certification which has implemented since 2007 until now has not shown clear results. It seemed that there is the only procedural step to gain additional allowance after having certificates ("Dialog Publik Pendidikan Nasional dan Halal Bi halal PGRI dengan Wakil Presiden R," 2018). The teacher certification programs have not contributed significantly to improving the quality of education at large. At the same time, World Bank (2013) launched its publication "Spending More or Spending Better: Improving Education Financing in Indonesia" indicating that there was no significant difference between certified and uncertified teachers in their learning achievement. Teacher certification programs contribute little to the improvement of national education quality. Even further, the World Bank reported the result of data collection from 2009 onward to observe the impact of teacher certification student learning at 240 public elementary schools and 120 junior high schools concluded neither significant difference between the two groups nor the influence of certified teachers on student achievement ("Spending More or Spending Better: Improving Education Financing in Indonesia," 2013). This educational phenomenon invited a critical number of questions and continued until the present day. Some researches on teacher certification policy in Indonesia, such as by Apriliyanti (2013), Triyatno (2012), and the World Bank (2012), Eddy Haryanto, et.all. found significant contribution to teacher's quality, particularly in case of their welfare through additional allowance gained after being certified. The Government - both central and local--have not evaluated comprehensively how the effectiveness of teacher's certification programs toward education quality improvement as a whole, including evaluation such program at the local level of implementation. This study tries to examine how teacher's certification program was implemented in Bogor Regency, West Java, Indonesia.

\section{Methods of Research}

The study uses an evaluation of the CIPP model (Context, Input, Process, and Product), with a qualitative approach (Stufflebeam, 1983; Stufflebeam \& Coryn, 2014). CIPP which was developed by Daniel Stufflebeam and colleagues in the 1960s is regarded as a popular evaluation approach in the educational setting (Fitzpatrick, Sanders, \& Worthen, 2011; Zhang et al., 2011) and it is a comprehensive framework for guiding evaluation programs due to understanding all component related to the program evaluated include context, input, process, and product evaluation or a combination of these elements(Stufflebeam, 1983) that can be used proactively and retroactively(Thurab-Nkhosi, 2019). The CIPP model is effectively functioned as a means of linking evaluation with program decision making. It aims to provide an analytic and rational basis for program decision making based on a cycle of planning, structuring, implementing, and reviewing and revising decisions, examining through a different aspect of evaluation viewed from context, input, process, and product spectra.

The context evaluation stage of the CIPP Model assists in decision making related to planning which enables the evaluator to understand the needs, assets, and resources of a community in order to provide programming that will be beneficial(Fitzpatrick et al., 2011) and also identifies political climates influencing the success of the program(Mertens \& Wilson, 2012).

The input evaluation, then, helps the evaluator collect information regarding mission, goals, and the plan of the program. The next stage is process evaluation which focuses on understanding the quality of program implementation. The final component of the CIPP model deals with product evaluation to assess the positive and negative effects the programs had on its target audience 
and assesses both intended and unintended outcomes (Kellaghan, Stufflebeam, \& Wingate, 2003).

The study aims to analyze the successes and failures of the implementation of the Junior high school teacher certification policy implemented by the Bogor District Education Office in the year of 2008-2014.

Data is collected through documentation studies to review various documents related to certification, such as regulations, planning, and certification guidelines. Interviews with purposive snowball sampling also took place to understand ideas, perceptions, and evaluations about input, process, and product of ongoing certification activities. The interview-target addressed to main stakeholders that is local bureaucrats, teacher-participants, and assessors. Observation is done to see the on-going activities of the certification program and its surrounding environments.

Data analysis begins with making field notes in the form of transcripts. The transcript is matched and given meaning, purpose, and purpose, and triangulation of sources, methods, investigators, and theories are carried out. Read over and over to be selected and coded. Coding is needed to facilitate repeated tracking of data. The next step is grouping and coding data according to sub-focus and evaluation aspects. Then do the merging of data in the form of a matrix or table, according to the evaluation aspects, followed by a conclusion in the form of a description of the results of the analysis and research findings

\section{Teacher's Certification in Bogor}

The Bogor Regency is located in the province of West Java and is adjacent to the south part of the Capital city of Jakarta. Geographically, Bogor is the largest regency amongst other surroundings of Jakarta, namely regencies of Depok, Tangerang, and Bekasi) and considered as a bedroom community for Jakarta and is home to over five million people $(5,131,798$ people) who live in 40 districts. Bogor is mostly urbanized, and more than 1,3 million people work in Jakarta.

In the case of the Teacher certification program, Bogor is one of the regencies in West Java and received a quota of 2,918 teachers or $0.97 \%$ of the national quota and was the fourth-largest quota winner in West Java Province. This indicates that the implementation of teacher certification, especially junior high school teachers, has not met expectations. The target of achieving nine offices performance indicators is only able to reach $23.32 \%$ of the planned target of $75.07 \%$. The absorption capacity of the certification operational budget reaches $97.05 \%$. While training and development activities after the certification of junior high school teachers have not been done programmatically.

In addition, it is known that the average junior high school teacher experiences arrears in the payment of professional allowances each month, more than the kindergarten, elementary, high school, and vocational school teachers. The existence of arrears has implications for the delay in disbursement of benefits with varying time, ranging from 3 months to 1 year. Even from the data search, information was obtained that several schools cut professional teacher allowances by Rp. 400,000 every quarter.

Seeing the fact that there are problems that arise, the evaluation of the implementation of the junior high school (SMP) teacher certification policy in Bogor Regency is an important thing to do. With this evaluation, it can be seen the consistency between the policies issued by the government, and their implementation in the field, starting from the office of education unit to the teachers themselves

Teachers' certification is fulfilling the need to realize truly professional teachers; therefore, certification is seen as an essential part of efforts to obtain competencies in accordance with established standards. Measuring teacher competence, known as the certification process, is certainly not easy. Valid and reliable measuring tools, structured observations, and track records are needed which are proven in objective assessments. Ideally, teacher certification is carried out through competency testing and professional practice from an independent Professional Certification Agency.

The seriousness of the government to certify teachers is proven by targeting all certified teachers in Indonesia in 2015, as stated in the RI Law on Teachers and Lecturers Number 14 of 2005 which states that, "teachers who do not yet have academic qualifications and educator certificates as referred to in this Law are required to meet academic qualifications and educator certificates no later than (10) years from the enactment of this law.

Moreover, there were concerns that the quality control mechanism in the teacher certification process was being undermined by the existing widespread practice of using illegal or forged documentation. Now most teachers have to follow the certification process through the teacher retraining channel. As the first step in this channel, prospective teachers have to pass a preliminary competency test. Teachers who pass this preliminary test will participate in 90 hours of retraining delivered in the form of lectures and workshops over 10 days. At the end of the retraining, they will undergo a final test. Those who pass the test will be considered as having sufficient competency to become teachers and will be deemed to be certified teachers. Those who do not pass either the preliminary or final test, on the other hand, will be considered as not having sufficient competency to become certified teachers

From 2007 until 2014, teacher certification underwent several changes, from the PSPL (Direct Educator Certification system, portfolio, Teacher Education and Professional Training (PLPG/ Pendidikan dan Latihan Profesional Guru), to Teacher Professional Education 
(Pendidikan Profesional Guru/PPG). Then, it continued using a new pattern through Professional Teacher Education in Position, (PPGJ) in 2015, and the enactment of Recognition of Past Learning (RPL). Based on data from the Unique Number of Educators and Education Personnel (NUPTK) -per 20 September 2011, the number of teachers nationally is $2,925,676$, with the details in the following table.

Table 1. Detail of National Teacher Status

\begin{tabular}{|c|l|l|l|}
\hline No & Description & Total & Percentage (\%) \\
\hline 1 & Teacher in 2011 & $2,925,676$ & - \\
\hline 2 & Teachers Meet Certification & $2,063,709$ & 70,5 \\
\hline 3 & Teachers certified & $1,102,021$ & 37,7 \\
\hline 4 & Certified Teachers passed & 746,727 & 25.5 \\
\hline 5 & $\begin{array}{l}\text { Teachers meet the } \\
\text { requirement are certified }\end{array}$ & 961,688 & 32,9 \\
\hline 6 & $\begin{array}{l}\text { Teachers do not meet the } \\
\text { certified requirement }\end{array}$ & 861,967 & 29,5 \\
\hline 7 & $\begin{array}{l}\text { Teachers receive the } \\
\text { professional allowance }\end{array}$ & 731,002 & 97,9 \\
\hline
\end{tabular}

Source: Bogor district education Bureau 2011

From these data, it is known that there are still $74.5 \%$ of national teachers who do not have teaching certificates. This prompted the government in 2012 to give provinces a quota of 300,000 teachers. West Java Province is the largest quota recipient province in Indonesia, with 43,349 teachers.

\section{Result \& Discussion}

\subsection{Teacher Certification: Objective, Target and Its Challenges}

As the most important component, the certification objectives set by the government are basically in line with the theory of good objective criteria. The objective was formulated clearly referring to the national policies concerning the laws and other related regulations on education and teacher certification in particular. The objective of the program is to increase the capacity and professionalism of education human resources, with the aim of fulfilling the number, qualifications, and competencies of teachers according to the MSS in order to meet national education standards at all levels of education. From the formulation of the vision, goals, and objectives, there are three work plans, namely: (1) improvement of academic qualifications, (2) improvement of teacher competency and certification, and (3) improvement of teacher welfare.

Thus, the objective formulated has a clear statement, using operational sentences so that its achievements are easily measured, as Thomas (2010) argues that goals should be well defined and operational and should reflect each unit's contribution to the entire organization (Foster, 2007). In the process of determination of teacher eligibility, selection system, qualification, and competency requirements, as well as a series of examinations carried out, are quite long and complicated. Increasing the professionalism and welfare of teachers through certification is carried out with a series of strategies and collaboration of various parties (District office, education units, teachers, and stakeholders). The certification objective has clear standards and time limits, such as the achievement target for 2012 is $33.24 \%$, and in 2013 that is $30.70 \%$, with 6,696 participants, from Bogor District Junior High School teachers, although in reality, it has not reached $100 \%$. But at least the existence of standards and time limits makes the purpose of certification in the directed corridor.

As of 2013, the teacher certification was targeted only at 2,609 certified teachers $(1,613$ civil servants and 996 non-civil servants). There is a quota gap between civil servant teachers and non-civil servant teachers, where civil servant teachers have more portions than non-civil servant teachers. This fitted with the target stated due to the certification handbook, it is clearly stated that civil servant teachers have a minimum quota of $75 \%$, and non-civil servant minimum of $25 \%$ according to the proportion of the number of teachers in each region. However, there are 4,087 SMP teachers who have not been certified, indicating that SMP teacher certification is an urgent need, especially for private teachers. With the remaining 4,087 SMP teachers who have not been certified, while the quota given by the Government is only 2,918 teachers (at all levels), just to be registered as a candidate for certification requires a long queue and quite a long time. It takes around 11 years for the Bogor District Education Office to be able to complete the teacher certification up to 2026.

There are two major problems faced by the Bogor District Education Office, in achieving the target of junior high school teacher certification, namely strategic factors and technical factors. The strategic factor is the lack of clarity in the 2015 certification pattern in which the system underwent several changes and often changed from one regular pattern to another new pattern without a reasonable explanation.

In the early period of implementation, as an example, teacher certification used PSPL by granting certificates directly to those who met their qualification. In the following years, the system used portfolio/appraisal and PLPG as measuring tools of teachers' competencies. In the next year of 2015, it had planned to enact the RPL (Recognition of Past Learning) system, although it finally fell to be implemented.

This fact resulted in not only any confusion of teachers regarding the target's priorities, but it also caused the low quality of the certification program in general. Until August at the end of 2015, there has been no clear target for certification participants. The technical factor is the 
disbursement of benefits which is often late, and results from mistakes in inputting data in The Basic Data of Education System (Sistem Data Pokok Pendidikan). Teacher's teaching load (24 hours) has not been met factually. Inactive accounts due to insufficient balances, and other technical constraints resulting in non-disbursement of SMP teacher allowance funds amounting to $\mathrm{Rp} 12,116,204,800$, with an average of arrears towards teachers reaching $\mathrm{Rp} 4,019,975$. The government actually gave an opportunity to the Bogor Regency Education Office with a quota of 2,918 people, the fourth largest quota recipient out of 32 regencies/cities in West Java. In addition, the Bogor District Office also has the authority to conduct socialization, selection, recruitment, program preparation for teacher competency test and to provide assistance for disbursement of teacher professional allowances. However, this opportunity does not appear to have been used maximally, so that various strategic and technical problems still occurred.

\subsection{Planning and Allocating Teacher Certification Resources}

Planning and allocation of resources is an integral part of the work system. The allocation of resources including the budget, human resources, and so on are important points that must be managed, especially when making decisions when plans will be made. The more precisely it allocates resources, the more targeted planning is planned, which in turn, will influence the successful implementation of teacher certification policies in a sustainable manner.

Planning for the teacher certification of the Bogor District Education Office is an integrated part of the 2014
Strategic Plan to 2018. The Strategic Plan stated the vision statement "The implementation of excellent education services to form quality people in order to realize the most advanced districts in Indonesia ".

In addition, the objective of the program is to increase the capacity and professionalism of education human resources, with the aim of fulfilling the number, qualifications, and competencies of teachers in order to meet national education standards at all levels of education. From the formulation of the vision, goals, and objectives, there are three work plans, namely: (1) improvement of academic qualifications, (2) Improvement of Teacher Competency and certification, and (3) improvement of teacher welfare.

The allocation of resources, in this case, the budgeting is also carried out in an integrated manner, although for the certification budget is certainly outside the budget because certification funding is obtained from the state budget. APBD funds are more programmed to support the success of certification, especially for the implementation of post-certification socialization and coaching.

\subsection{The Implementation of Teacher Certification}

The implementation of teacher certification begins with socialization, assignment of participants, certification paths as well as teacher training and development. Even though the socialization has been going on for more than 4 years, it turns out that the contents or materials of the socialization have not included all information related to teacher certification. Interviewees tend to just read the rules without explaining the possible problems that will occur. 


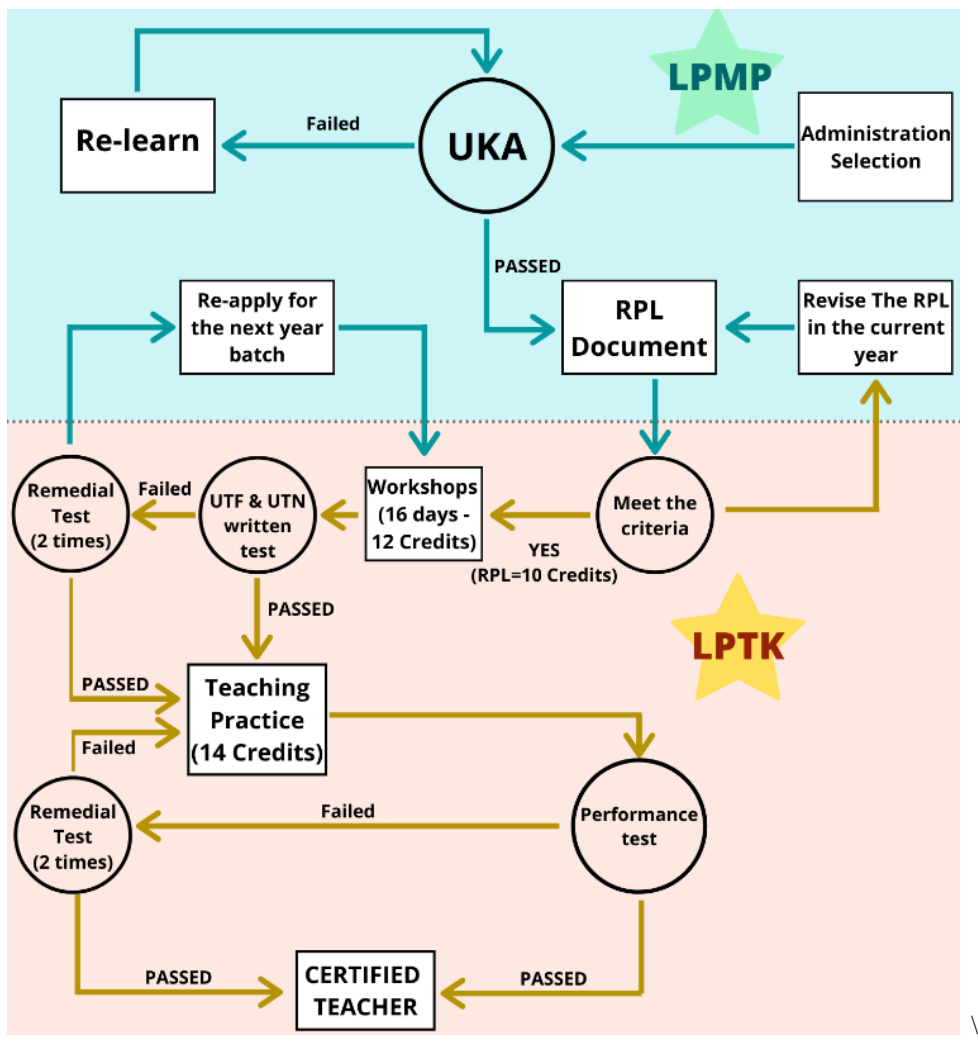

Figure 1. Teacher Certification Path 2015

From Figure 1, it is known that certification is carried out through a long series. Using the RPL system (Recognition of Prior Learning) which must be taken equivalent to 10 credits, followed by training/workshops equivalent to 12-semester credit system (Sistem Kredit Semester), as well as various tests, including performance tests before getting an educator certificate. The success of the certification is, of course, not only determined by the certification system alone but also determined by the quality of the facilitator, the availability of facilities, media tools, and teaching materials during the training/workshop (Widoyoko, 2008). No less important, the participation and enthusiasm of the participants during the training/workshop process were also decisive. Unpreparedness breeds formalism in certification. Any assumption that anyone who participates in a training/workshop will eventually graduate becomes the truth.

The formalism of certification will occur when certification is a single system that is not integrated with the system of recruitment, coaching (training), evaluating teacher performance itself. This recruitment system is very important because it was allegedly the first step to improve education in a country. It is mentioned that improving quality teaching administration of education depends on first improving recruitment, training, social status, and conditions work of teachers(Soedijarto, 2008).

The guidance system (supervision) is a continuous professional assistance service in the form of training and others are also important in order to continuously improve the quality of teacher teaching. Furthermore, incentives, in this case, the provision of certification allowances based on the process and work products of teachers, including student learning outcomes/achievements, which are factually measured are things that need attention. A single certification that is not integrated makes certification the main target of teachers, to save their lives. After that how the actual performance and how the impact of the certificate on student learning outcomes is not a problem for them, which in turn the quality of teaching and learning of student learning outcomes remain unchanged, but still as before.

A single certification system by competing with teachers in various regions is done in China, for example. Who is selected, who wins the competition gets teacher certification. The positive impact of this competition system is that all teachers are competing to graduate to get an award from the government, and are selected as professional teachers.

\subsection{Impact of Certification on Performance of Teachers}

There are differences in performance between certified teachers and uncertified teachers, which are obtained from the results of the performance appraisal including (1) administration of learning planning, (2) administration of learning assessment, and (3) teaching and learning activities, can be seen in the following figure. 


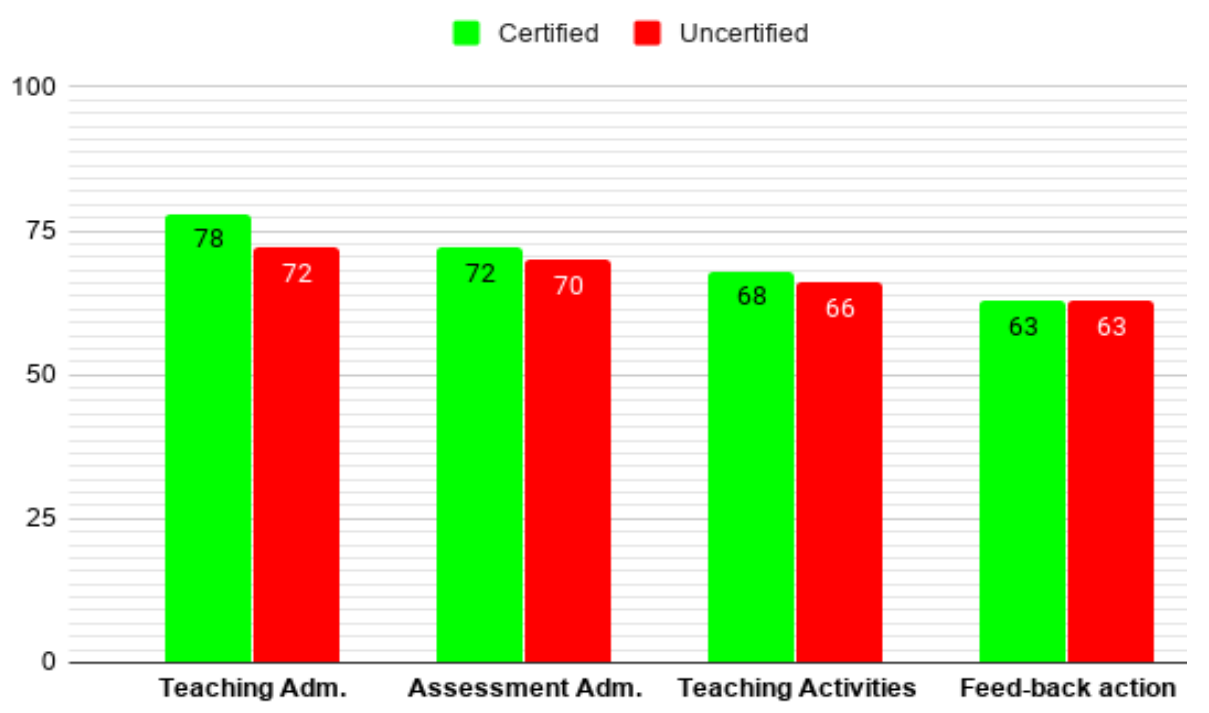

Figure 2. Teacher Performance Comparison (in Percentage): Bogor Regency Statistical Bureau

From figure 2, it can be seen that there was no difference between the certified and uncertified teachers. In other words, its difference was not significant with a difference of 2,5 points. The performance of categorized professional teachers is on average point, with an average grade of 70,25. Whereas uncertified teachers are categorized as low-performing. The acquisition of these values was correlated with the acquisition of UKG (Uji Kompetensi Guru/ Teacher Competency Test) values. Teachers with high UKG scores generally have high performance. Thus, UKG scores affect teacher performance. In addition, workshops/training that has been undertaken has contributed to performance, in addition to psychological factors with obtaining certification allowances, they also have an effect. Therefore, to maintain consistency in teacher performance, class-based performance appraisals are needed on post-certification continually(Karami-akkary, 2019), in addition to assessing student learning outcomes in the form of competency achievement levels as evidence of teacher's real performance products. This suggestion is in line with Wolf \& Peele (2019) work that found the teacher's well-being and classroom practices in one year has decreased the performance.

This is the same as what Chile did, educator certificates were given if teachers and schools were able to reach the competency standards of their students' graduates. This means that performance must be demonstrated before an educator certificate is obtained. Each teacher will try to meet the target achievement of student competency standards. The teacher always strives to master the material to be delivered, improve teaching methods, update learning tools and media, improve conducive communication with students, and make improvements to the assessment system to have a high degree of accuracy which is reflected in the actual competence of students. Concurrently, the Bogor District Education Office from 2013 to 2018 is targeting to carry out post-certification performance assessments of
35,272 teachers, with a budget allocation of $\mathrm{Rp}$ $1,901,938,000$. However, the performance evaluation has not touched the achievement of student competency standards that reflect the performance of the teacher himself.

\subsection{Impact of Certification on Teacher Welfare}

The welfare of certified teachers has generally increased, although, for non-civil servant teachers, it has only been able to meet the basic needs of daily life. Old-age insurance, recreation, children's education, are still not affordable. The use of funds properly for basic needs has not been able to set aside to improve quality and purchase materials. In fact, the government has explicitly mandated by law that the allowance given to certified teachers must meet the minimum needs, including clothing, food, shelter, recreation, health, old-age insurance, both for the teacher himself and for his family. Yet, the increased income would secure the teacher's job or profession (Kobakhidze, 2013).

The difference in income of certified civil servant teachers from certified non-civil servant teachers and non-certified civil servant teachers is notable. Especially when compared to the UMR Regency of Bogor, Non-civil servant teachers have not been certified quite apprehensive. Complete income differences with the assumption of group 3 civil servant teachers, and the average non-civil servant teacher income can be seen in the Figure 3.

When compared to the Bogor Regency/City minimum regional wage of Rp. 2,590,000,- certified teachers have a greater income of Rp. 1,710,000,- -- Rp. 3,010,000,compared to workers in each month. While those who are not yet certified, earn below the regional minimum wage of Rp. 290,000,- - Rp1,965.000,- This data indicates that certified teachers, especially civil servants, are more prosperous than private school teachers. 


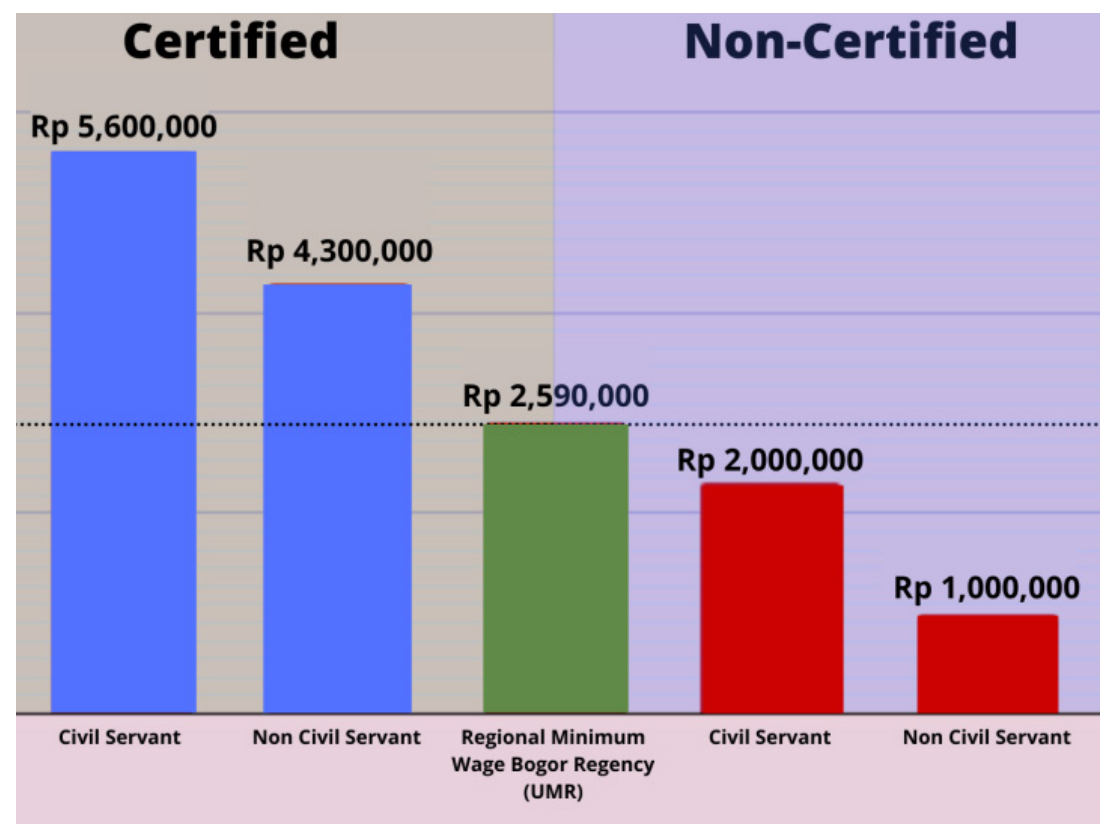

Figure 3. Bogor Teacher's Income (Bogor Regency Statistical Bureau)

The welfare of uncertified civil servant teachers is very alarming. Income obtained is far below the regional minimum wage. Whereas in general teachers with Bachelor education background, with an average work period of more than 5 years. This condition certainly has an impact on teacher performance which in turn affects the quality of student learning.

\subsection{Impact of Certification on Fulfilling the Demands of Teaching Hours}

One of the requirements for disbursing certification allowance is the fulfillment of 24 teaching hours per week. Not all teachers can meet the required number of teaching, because of the limited study group at the school where the teacher teaches. Actually, the school should have the plan for the development of the teacher (Pharis, Wu, Sullivan, \& LaSonya, 2019) So, the school could support the teacher for maintaining requirements (Kimathi \& Bertram, 2019). Consequently, the teacher concerned must find another school to increase the number of teaching hours, and the teacher who has not been certified must be willing to release the teaching schedule to the certified teacher. This condition results in increasingly limited opportunities for uncertified teachers to obtain adequate teaching hours, which has implications for the lack of income, thus further aggravating the income gap of certified teachers and uncertified teachers. Social jealousy occurs, giving birth to a school climate that is not conducive. This issue seems to have become common knowledge. Fulfillment of the number of teaching hours is done by "win-win solution". Usually, certified teachers share sustenance with teachers whose teaching hours are taken. This condition has been known by various parties. Know and know. Each other overlaps. There has been systematic fraud, worsening the image of teachers, which in turn has worsened the image of education itself. Then, the suggestion on the importance of School-Based Professional Learning Study was supported by this study that school planning for the teacher should be data provided some evidence of the effectiveness of school-based planning focused on timely and continuous professional development for teachers.

\subsection{Impact of Certification on Teacher Academic Attitudes}

One indicator of the positive impact of the certification includes an increase in teacher academic attitudes in writing scientific papers, writing teaching materials and modules, making media, and increasing the intensity of student academic guidance. In reality, in Bogor Regency, indications that direction has not yet been seen. Academic attitudes of post-certification teachers are generally still as before. The training/workshops that have been undertaken have not been able to change their academic attitudes. Readiness to conduct self-evaluation, and willingness to improve the quality of teaching through independent training have not grown well. Teaching is not a challenging job but a routine without updates. The target of fulfilling the number of hours and completing the delivery of material becomes the priority. While the strategies for achieving student competency standards have not been carried out optimally, they are even formalities without serious efforts.

\section{Conclusions}

This paper described the Teacher Certification Bogor, focusing on the problem of how effectiveness of the 
program implemented in the Local Government of Bogor regency. The study concluded some important findings.

First, the program of teacher certification that has been implemented since the year of 2008-2015 was in accord with the national policy of the Central Government. The objective, planning, vision, and activities of the program were in line with the Central Government rules and guide-book. The objectives set by the government are well defined, have clear time limits, are operationalized, and are well understood. However, the local Government seemed not to provide the operating procedure to organize activities in a detail that potentially caused low of the program effectiveness.

Second, planning and allocation of human resources have been classified properly, based on sources, allocation of funds, implementation time, and performance indicators, making it easier for the agency to implement this certification policy. Although the budget allocation of the program seemed adequate, the local government is still faced with any challenges or difficulties dealing with any supply of supporting facilities, unpreparedness of local human resources, and the failure of granting allowance to certified teachers. In addition, the monitoring and evaluation system was not prepared in a systematic way that consequently could not be operated effectively to evaluate the program.

Third, the results of certification in terms of teacher performance have shown little difference between the certified and uncertified teachers. The teacher certification has not contributed significantly to improving teacher competencies and student's achievement. What most significantly gained from the teacher certification program, is the increase of certified teachers' income due to their additional allowance after being certified.

Finally, the study suggested to the Local Government to reorganize the following program in terms of: (a) human resources preparation of local government, (b) completeness of facilities and infrastructures, (iii) revaluation on whether the product has been in accordance with main objective and target of teacher certification program itself, (iv) the developing of best pattern for professional improvement of the teachers in nature.

\section{Acknowledgments}

We are very grateful to the postgraduate school of Universitas Negeri Jakarta that provides the funding for this study.

\section{REFERENCES}

[1] Abbas, H. (2013). Inconvenient truths about teacher certification program. The Jakarta Post. Retrieved from https://www.thejakartapost.com/news/2013/04/27/inconve nient-truths-about-teacher-certification-program.html

[2] Brotosedjati, S. (2012). KINERJA GURU YANG TELAH LULUS SERTIFIKASI GURU DALAM JABATAN. Jurnal Manajemen Pendidikan, 1(2), 189-199.

[3] Chetty, R., Friedman, J. N., \& Rockoff, J. E. (2013). MEASURING THE IMPACTS OF TEACHERS I: EVALUATING BIAS IN TEACHER VALUE-ADDED ESTIMATES. Cambridge, MA 02138. Retrieved from http://www.nber.org/papers/w19423\%0A

[4] Darling-hammond, L. (2000). Teacher Quality and Student Achievement : A Review of State Policy Evidence Previous Research. EDUCATION POLICY ANALYSIS ARCHIVES, $8(1), 1-44$.

[5] Darling-hammond, L. (2002). Research and Rhetoric on Teacher Certification: A Response to "Teacher Certification Reconsidered". Education Policy Analysis Archives, 10(36), 1-55.

[6] Darling-hammond, L., Holtzman, D. J., Gatlin, S. J., \& Heilig, J. V. (2005). Does Teacher Preparation Matter? Evidence about Teacher Certification, Teach for America, and Teacher Effectiveness. EDUCATION POLICY ANALYSIS ARCHIVES, 13(42), 1-49.

[7] Dewanto, D. H., Erviantono, T., \& Winaya, I. K. (2016). Pengaruh Sertifikasi Terhadap Kinerja Guru di SMA N 1 Gianyar (The Influence of Teacher's Certification Program towards Teacher's Performance at SMAN 1 Gianyar). Citizen Charter, 1(1), 1-10.

[8] Dialog Publik Pendidikan Nasional dan Halal Bi halal PGRI dengan Wakil Presiden R. (2018).

[9] Fitzpatrick, J. L., Sanders, J. R., \& Worthen, B. R. (2011). Program Evaluation: Alternative Approaches and Practical Guidelines (4th ed.). Newyork: Pearson.

[10] Foster, S. T. (2007). Managing quality: integrating the supply chain (3rd ed.). New Jersey: Pearson Education International.

[11] Fuad, N. (2017). PENGARUH SERTIFIKASI GURU TERHADAP PENINGKATAN KINERJA GURU PAI DI SMP DAN MTs Nurhattati Fuad \urnal Manajemen Pendidikan, 8(1), 23-32.

[12] Goe, L., \& Stickler, L. M. (2008). Teacher Quality and Student Achievement: Making the Most of Recent Research. Washington DC: National Comprehensive Center for Teachdr Quality. Retrieved from www.ncctq.org

[13] Goldhaber, D. D., \& Brewer, D. J. (2000). Does Teacher Certification Matter? High School Teacher Certification Status and Student Achievement. Educational Evaluation and Policy Analysis, 22(2), 129-145. https://doi.org/10.3102/01623737022002129

[14] Greenwald, R., Hedges, L. V, \& Laine, R. D. (1996). The Effect of School Resources on Student Achievement Review of Educational Research, 66(3), 361-396. https://d oi.org/10.3102/00346543066003361

[15] GUSTINA, L. (2016). PENGARUH SERTIFIKASI GURU TERHADAP KINERJA GURU. Universitas Lampung.

[16] Jalal, F., Samani, M., Chang, M. C., Stevenson, R., Bagatz, 
A. B., \& Negara, S. D. (2009). Teacher Certification in Indonesia: A Strategy for Teacher Quality Improvement.

[17] Kane, T. J., Rockoff, J. E., \& Staiger, D. O. (2008). What does certification tell us about teacher effectiveness? Evidence from New York City. Economics of Education Review, 27, 615-631.https://doi.org/10.1016/j.econedurev. 2007.05.005

[18] Karami-akkary, R. (2019). Evaluating teacher professional learning in the Arab region; the experience of the TAMAM project. Teaching and Teacher Education, 85, 137-147. https://doi.org/10.1016/j.tate.2019.06.008

[19] Kellaghan, T., Stufflebeam, D. L., \& Wingate, L. A. (Eds.). (2003). International Handbook of Educational Evaluation Part One : Springer.

[20] Kimathi, F. K., \& Bertram, C. A. (2019). How a professional development programme changes early grades teachers' literacy pedagogy. South African Hournal of Chilhood Education, 9(1), 1-11.

[21] Kulshrestha, A. K., \& Pandey, K. (2013). TEACHERS TRAINING AND PROFESSIONAL COMPETENCIES. Voice of Research, 1(4), 29-33.

[22] Maister, D. H. (1997). True Professionalism: The Courage to Care about Your People, Your Clients, and Your Career. Newyork: Free Press.

[23] Mertens, D. M., \& Wilson, A. T. (2012). Program Evaluation Theory and Practice : A Comprehensive Guide. Newyork: Guilford Press.

[24] Miguel, M. M. ., \& Barsaga, E. B. . (1997). Multi-grade schooling in the Philippines, a strategy for improving access to and quality of primary education. In From Planning to action: government initiatives for improving school-level practice (pp. 117-131).

[25] Pharis, T. J., Wu, E., Sullivan, S., \& LaSonya, M. (2019). Improving Teacher Quality: Professional Development Implications from Teacher Professional Growth and Effectiveness System Implementation in Rural Kentucky High Schools. Educational Research Quaterly, 42(3), 2949.

[26] Rice, J. K. (2003). Teacher Quality: Understanding the Effectiveness of Teacher Attributes. Economic Policy Institute.

[27] Rivkin, S. G., Hanushek, E. A., \& Kain, J. F. (2005). Teachers, schools, and academic achievement Econometrica, 73(2), 417-458.

[28] Soedijarto. (2008). Landasan dan arah pendidikan nasional kita. Jakarta: Penerbit Buku Kompas.

[29] Spending More or Spending Better: Improving Education Financing in Indonesia. (2013). Retrieved from https://www.worldbank.org/en/news/press-release/2013/03 /14/spending-more-or-spending-better-improving-educatio n-financing-in-indonesia

[30] Stufflebeam, D. L. (1983). Educational evaluation and decision making. Itaca, Illionis: Peacock Publisher, Inc.

[31] Stufflebeam, D. L., \& Coryn, C. L. S. (2014). Daniel Stufflebeam's CIPP model for evaluation: An improvement and accountability oriented approach. In Evaluation theory, models, and applications: Research methods for the social sciences (pp. 309-340). https://doi.org/10.1016/j.jpainsym man.2005.09.001

[32] Sutopo. (2017). FAKTOR-FAKTOR YANG MEMPENGARUHI KINERJA GURU SMK BIDANG PRODUKTIF PASCA SERTIFIKASI. Jurnal Dinamika Vokasional Teknik Mesin, 2(April), 37-48.

[33] Thurab-Nkhosi, D. (2019). The evaluation of a blended faculty development course using the CIPP Framework. International Journal of Education and Development Using Information and Communication Technology, 15(1), 245254.

[34] Ulfah, S. (2012). EFEKTIFITAS SERTIFIKASI TERHADAP KINERJA GURU DI SMP MUHAMMADIYAH 10 SURAKARTA. Universitas Muhammadiyah Surakarta.

[35] Undang Undang Republik Indonesia No 14 Tentang Guru dan Dosen (2005).

[36] Vieira, C., \& DeVoogd, G. (2013). How Teacher Certification Programs Must Change to Meet the Growing Demand for Online Classes. In Society for Information Technology \& Teacher .... https://doi.org/10.1098/rsta.201 1.0605

[37] Widoyoko, S. E. P. (2008). PERANAN SERTIFIKASI GURU DALAM MENINGKATKAN MUTU PENDIDIKAN. Purworejo. Retrieved from http://www.umpwr.ac.id/publik asi-ilmiah/290-peranan-sertifikasi-guru-dalam-meningkatk an-mutu-pendidikan.html

[38] Wolf, S., \& Peele, M. E. (2019). Examining sustained impacts of two teacher professional development programs on professional well-being and classroom practices. Teaching and Teacher Education, 86, 102873.https://doi.o $\mathrm{rg} / 10.1016 /$ j.tate.2019.07.003

[39] Zhang, G., Zeller, N., Griffith, R., Metcalf, D., Williams, J., Shea, C., \& Misulis, K. (2011). Guili Zhang, Nancy Zeller, Robin Griffith, Debbie Metcalf, Jennifer Williams, Christine Shea, and Katherine Misulis. Journal of Higher Education Outreach and Engagement, 15(4), 57-84. 